\title{
AN UNUSUAL CLINICAL RECOVERY FROM SYSTEMIC LUPUS ERYTHEMATOSUS
}

\author{
BY \\ G. A. ROSE \\ From the Medical Unit, St. Mary's Hospital, London
}

This case is reported for two reasons. First, it illustrates that lupus nephropathy with renal failure and severe hypertension is not necessarily fatal, and that the hypertension may be reversible; secondly, the patient's unexpected recovery followed the menopause.

\section{Case Report}

A housewife aged 51 came to hospital in July, 1955, complaining that for the previous 2 months she had suffered from attacks of pain in her right arm; these occurred principally at night, but were also provoked by peeling potatoes or carrying shopping. On direct questioning it appeared that for about 3 months she had not been completely well: her appetite had been poor and, contrary to her usual custom, she had been getting up at night to pass urine. Some 3 weeks previously she had had transient painful swelling of her right ankle, and for 1 week she had noticed a patchy non-irritating rash on her face and neck. She also mentioned that all her life her skin had tended to become blotchy after exposure to sunlight.

On examination she was febrile $\left(99 \cdot 8^{\circ} \mathrm{F}\right.$.). Her face and neck were covered by a symmetrical red scaling macular rash, sparing only the area around her eyes. Around the nail-folds of her fingers were red chilblainlike lesions. Her blood pressure ranged from 130 to $140 / 70$ to 80 . The urine contained $0 \cdot 3$ per cent. protein. with numerous red and white blood cells. $X$ ray of the cervical spine showed clear evidence of disc degeneration, and this was presumed to have caused the pain which brought her to hospital.

Her erythrocyte sedimentation rate (Westergren) was at first $18 \mathrm{~mm} . / 1 \mathrm{hr}$, but within 2 weeks it had risen to $66 \mathrm{~mm}$. Other tests showed: $\mathrm{Hb} 75$ per cent., red blood cells 3.9 million $/ \mathrm{mm}^{3}$, white blood cells $5,000 / \mathrm{mm}^{3}{ }^{3}$ (neutrophils 2,600/mm. ${ }^{3}$ ). Blood urea $63 \mathrm{mg} . / 100 \mathrm{ml}$. Plasma proteins $6.9 \mathrm{~g} . / 100 \mathrm{ml}$. (albumin $3 \cdot 7$, globulin 3.2). Paper electrophoresis: increase in gamma-2 globulin (14 per cent.). L.E. cells were seen in peripheral blood. A urine concentration test showed a maximum urinary specific gravity of $1 \cdot 022$. Chest $x$ ray and intravenous pyelogram were normal.
A diagnosis was made of systemic lupus erythematosus (S.L.E.) with renal involvement, and treatment with cortisone was started on August 12, 1955. She was discharged from hospital 3 weeks later on $150 \mathrm{mg}$. cortisone daily. Her rash faded quickly, well-being and appetite improved, and the erythrocyte sedimentation rate fell to $14 \mathrm{~mm} . / 1 \mathrm{hr}$. Proteinuria and microscopic haematuria persisted.

On September 13, 1955, her blood pressure was found to be $180 / 105$, and by November 22,1955 , it was $250 / 145$. She was now re-admitted to hospital. Both optic discs were swollen, although there were no haemorrhages or exudates. Her face was moon-shaped, her complexion greasy, and her ankles oedematous. The blood urea had risen to $92 \mathrm{mg}$. $/ 100 \mathrm{ml}$; the maximum urinary specific gravity after dehydration was 1.018 , and the urea clearance values were 29 and 33 per cent. or normal.

Because of the oedema, cortisone was replaced by prednisone, stabilizing at $50 \mathrm{mg}$./day. The hypertension was moderately controlled by oral pentolinium tartrate. Her general condition gradually improved, the appearance of the optic discs became normal, and by June, 1956, the blood urea had fallen to $47 \mathrm{mg}$. $/ 100 \mathrm{ml}$. The dose of prednisone was reduced progressively. By February, 1957, the urine was free of protein, although it still contained granular casts and red and white blood cells.

During 1958 the patient's menses ceased, and during the next 2 years she was troubled by hot flushes and sweats.

In August, 1958, prednisone was withdrawn altogether. The patient, however, "felt awful", and complained much of muscle and joint pains. The blood pressure at the end of this 6-week steroid-free period was still $140 / 110$, despite pertolinium. Prednisone $2.5 \mathrm{mg}$. daily was re-started, but 3 months later it proved possible to withdraw both steroid and hypotensive drugs.

The patient was seen regularly for a period of 18 months after therapy was stopped. After some initial fatiguability, she gradually regained a feeling of normal fitness and returned to full-time employment. Her blood pressure has averaged $140 / 87$ (range 125 to $155 / 80$ to 90 ). Her erythrocyte sedimentation rate has ranged from 10 to $15 \mathrm{~mm} . / 1 \mathrm{hr}$, and her blood urea from 42 to $49 \mathrm{mg}$./ $100 \mathrm{ml}$. The urine has usually been protein-free, though 
a faint trace has been detected on occasion; the deposit has consistently revealed increased numbers of white blood cells and some granular casts.

\section{Discussion}

In their account of lupus nephritis, Muehrcke, Kark, Pirani, and Pollak (1957) noted that, in two patients with only mild renal injury, exacerbations of disease seemed to be associated with reversible hypertension; but in their experience severe hypertension, or hypertension associated with severe renal injury, was never reversed. Harvey, Shulman, Tumulty, Conley, and Schoenrich (1954), in their description of 138 cases of S.L.E., mentioned only one patient in whom the hypertension disappeared, and even then it had never been great, having ranged from 160 to $175 / 90$ to 110 . Recovery from severe hypertension does not seen to have been recorded hitherto in any case of S.L.E.

In the patient described here, the blood pressure level showed some correlation with steroid dosage; the pressure began to rise 1 month after treatment was started, and the highest pressures coincided with the highest doses. On the other hand the hypertension was also correlated with the severity of the nephritis, as judged by renal function and proteinuria. The relative importance of these two factors cannot be properly determined, but certain relevant observations may be stressed. First, malignant hypertension is an unlikely complication of steroid therapy per se; and similarly it is unlikely that the daily dose of $10 \mathrm{mg}$. prednisone given during the 3rd year could have been wholly responsible for diastolic pressures which-despite pentolinium-rose on occasion to $125 \mathrm{~mm}$. Secondly, when at the end of the 3rd year steroid therapy was stopped, the diastolic pressure 6 weeks later was still $110 \mathrm{~mm}$.- -again despite pentolinium. For these reasons it seems likely that this patient's hypertension was due primarily to lupus nephritis, although it may have been aggravated by steroid treatment.

At one stage of her illness she had florid generalized disease, azotaemia, malignant hypertension, heavy proteinuria, and oedema. Her ultimate recovery is still not assured, and she has certainly suffered a measure of irreversible renal injury. But the fact that she is symptomatically a fit person leading a normal life indicates that the physician faced with such a case should not wholly despair nor pursue only half-hearted therapy.

This unusual recovery occurred at approximately the same time as the patient's menopause. A number of other observations also suggest that the female sex hormones may exert an unfavourable influence on the dissemination and course of this disease:

(1) Discoid lupus erythematosus shows only slight female preponderance in incidence. Gold: (1960) reported 105 cases of clinically uncomplicate ff discoid disease. After the exclusion of cases witlo a raised erythrocyte sedimentation rate, the female $\frac{9}{5}$ male ratio in the remainder was only $1 \cdot 3$. Further more, there was no clear rise in this ratio during the female reproductive years: the ratio for the 3rof and 4th decades was the same as that for the res $\vec{b}$ of life.

The incidence of systemic lupus erythematosus $\vec{\omega}$ on the other hand, shows a heavy female prepon derance. Table I combines the data from two large series, totalling together 212 cases (Harvey ando others, 1954; and Medical Research Councilsw unpublished). There is a striking rise in the female $\mathbb{\infty}_{0}$ male ratio during the 3 rd and 4th decades, althoughf at all ages (except for the 1st decade) the ratio is higher than for discoid disease. A steadily pro- $\overrightarrow{-}$ gressive fall after the 3rd decade is interrupted bxd a rise in the $60+$ age group. This may be a vagary due to small numbers; but there was a similar trend in a series of discoid cases reported by Goldo (1960), among whom there were ten females aged 60 and over, but no males.

$$
\text { TABLE } 1
$$

INCIDENCE OF SYSTEMIC LUPUS ERYTHEMATOSUS BY AGE (AT DIAGNOSIS) AND SEX, BASED ON COMBINED DATA OF HARVEY AND OTHERS (1954) AND THE MEDICAL RESEARCH COUNCIL (UNPUBLISHED)

\begin{tabular}{|c|c|c|c|}
\hline \multirow{2}{*}{$\begin{array}{l}\text { Decade of } \\
\text { Onset }\end{array}$} & \multicolumn{2}{|c|}{ Number of Cases } & \multirow{2}{*}{ Female Male Rati } \\
\hline & Female & Male & \\
\hline 1 & 2 & 3 & 0.7 \\
\hline 2 & 28 & 8 & $3 \cdot 5$ \\
\hline 3 & 46 & 4 & $11 \cdot 5$ \\
\hline 4 & 46 & 7 & $6 \cdot 6$ \\
\hline 5 & 27 & 8 & $3 \cdot 4$ \\
\hline 6 & 14 & 5 & $2 \cdot 8$ \\
\hline $7+$ & 13 & 1 & $13 \cdot 0$ \\
\hline Total & 176 & 36 & $4 \cdot 9$ \\
\hline
\end{tabular}

(2) It has been suggested by Soffer, Ludemann, $\stackrel{7}{\mathrm{O}}$ and Brill (1955) and by Rupe and Nickel (1959). that systemic lupus erythematosus tends to be moreos severe among women than among men. Theren appear at present, however, to be no factual obser-N vations to confirm this suggestion.

(3) Some clinicians have formed the impression that, among females with the disease, mortality is higher during the reproductive years. Again, figures to support this contention do not seem to be 
available. Merrell and Shulman (1955) estimated the prognosis in their series of cases of systemic lupus erythematosus, using a life table procedure. Their data may be used to form separate estimates of prognosis in women aged respectively under 45 , or 45 and over, at diagnosis (Table II). The estimated survival rates at 2 years from diagnosis are not significantly different. (The true risk of dying from S.L.E. among the older group of women is probably less than appears in the Table, because of their relatively greater risk of dying from other causes.) It thus appears that a higher case fatality rate among younger women cannot at present be substantiated. On the other hand, Pollak (1961) has found that the risk of exacerbation of S.L.E. is very much greater during the first 8 weeks post partum than it is during pregnancy.

(4) Through the courtesy of the United States National Office of Vital Statistics, figures were made available for the numbers of deaths from lupus erythematosus in the United States, by age and sex, for the period 1956-58. In Table III these are presented as age-specific death rates. It can be seen that the male rate rises more or less steadily throughout life. At the extremes of life, the female rates are very similar to the male; but they are a great deal higher than the male rates for the quinquennia from 10-14 up to 50-54, and especially for the period between 20 and 49 years of age.

In order to obtain a more specific measure of the true mortality excess among females, one may deduct from the female rate at each age the corresponding male rate. (This procedure is based on the assumption that the changes in male rates with age represent a non-specific age effect which is likely to be common to both sexes.) The results are shown graphically in the Figure (overleaf), which also
TABLE III

DEATH RATES FOR LUPUS ERYTHEMATOSUS BY AGE AND SEX, UNITED STATES, ALL RACES, 1956-58 (FROM UNPUBLISHED DATA OF NATIONAL OFFICE OF VITAL STATISTICS)

\begin{tabular}{|c|c|c|c|}
\hline \multirow{2}{*}{$\underset{\text { (yrs) }}{\text { Age }}$} & \multicolumn{3}{|c|}{ Deaths per $10^{6}$} \\
\hline & Female & 1 & Male \\
\hline $\begin{array}{l}<5 \\
5- \\
10- \\
15- \\
20- \\
25- \\
30- \\
35- \\
40- \\
45- \\
50- \\
55- \\
60- \\
65- \\
70- \\
75 \text { and Over }\end{array}$ & $\begin{array}{l}0 \cdot 04 \\
0 \cdot 30 \\
1 \cdot 33 \\
2 \cdot 79 \\
3 \cdot 59 \\
2 \cdot 66 \\
3 \cdot 08 \\
3 \cdot 86 \\
3 \cdot 45 \\
3 \cdot 60 \\
3 \cdot 29 \\
2 \cdot 34 \\
2 \cdot 30 \\
1 \cdot 83 \\
2 \cdot 10 \\
2 \cdot 24\end{array}$ & 1 & $\begin{array}{l}0.03 \\
0.18 \\
0.13 \\
0.61 \\
0.33 \\
0.48 \\
0.73 \\
0.40 \\
0.90 \\
1.03 \\
1.55 \\
1.96 \\
1.78 \\
2.02 \\
2.23 \\
1.34\end{array}$ \\
\hline
\end{tabular}

indicates the age-specific means for urinary oestrogen excretion, as determined by a study of 704 normal women by Pedersen-Bjergaard and Tønnesen (1948). The correspondence between the changes in excess female mortality from lupus erythematosus and the changes in oestrogen levels is quite close.

This remarkable mortality phenomenon is not shown by any other disease, apart from diseases of the female reproductive organs and the complications of pregnancy. The complete contrast between the age and sex patterns for systemic L.E. incidence and mortality on the one hand, and discoid L.E. incidence on the other, presents difficult but stimulating problems.

These observations favour, although they do not prove, the hypothesis that the female sex hormones tend to provoke or aggravate systemic lupus erythematosus. The evidence might be considered sufficient to justify the trial of androgen therapy or

TABLE II

LIFE TABLES SHOWING PROBABILITY OF SURVIVING AMONG WOMEN WITH SYSTEMIC LUPUS ERYTHEMATOSUS, AGED UNDER 45 YEARS, AND 45 YEARS AND OVER

(DATA OF MERRELL AND SHULMAN, 1955)

\begin{tabular}{|c|c|c|c|c|c|c|c|c|}
\hline \multirow[b]{2}{*}{$\begin{array}{c}\text { Age } \\
\text { (yrs) }\end{array}$} & \multirow{2}{*}{$\begin{array}{c}\text { Period from } \\
\text { Diagnosis } \\
\text { (mths) }\end{array}$} & \multicolumn{4}{|c|}{ No. of Cases } & \multirow{2}{*}{$\begin{array}{l}\text { Probability } \\
\text { of Dying } \\
\text { in Period }\end{array}$} & \multirow{2}{*}{$\begin{array}{c}\text { Probability } \\
\text { of } \\
\text { Surviving }\end{array}$} & \multirow{2}{*}{$\begin{array}{c}\text { Cumulative } \\
\text { Probability } \\
\text { of Surviving }\end{array}$} \\
\hline & & $\begin{array}{c}\text { Entering } \\
\text { Period }\end{array}$ & $\begin{array}{l}\text { Follow-up } \\
\text { Terminated } \\
\text { in Period }\end{array}$ & $\begin{array}{c}\text { Dying in } \\
\text { Period }\end{array}$ & | At Risk, & & & \\
\hline Under & $\begin{array}{c}0- \\
6- \\
12- \\
18-23\end{array}$ & $\begin{array}{l}66 \\
49 \\
34 \\
24\end{array}$ & $\begin{array}{r}99 \\
12 \\
7 \\
6\end{array}$ & $\begin{array}{l}8 \\
3 \\
3 \\
1\end{array}$ & $\begin{array}{l}61 \cdot 5 \\
43 \cdot \\
30 \cdot 5 \\
21\end{array}$ & $\begin{array}{l}0.130 \\
0.070 \\
0.098 \\
0.048\end{array}$ & $\begin{array}{l}0.870 \\
0.930 \\
0.902 \\
0.952\end{array}$ & $\begin{array}{l}0.87 \\
0.81 \\
0.73 \\
0.69\end{array}$ \\
\hline $\begin{array}{l}45 \text { and } \\
\text { Over }\end{array}$ & $\begin{array}{c}0- \\
6- \\
12- \\
18-23\end{array}$ & $\begin{array}{r}18 \\
13 \\
10 \\
8\end{array}$ & $\begin{array}{l}1 \\
2 \\
1 \\
3\end{array}$ & $\begin{array}{l}4 \\
1 \\
1 \\
0\end{array}$ & $\begin{array}{c}17 \cdot 5 \\
12 \\
9.5 \\
6 \cdot 5\end{array}$ & $\begin{array}{l}0.229 \\
0.083 \\
0 \cdot 105 \\
0.000\end{array}$ & $\begin{array}{l}0.771 \\
0.917 \\
0.895 \\
1.000\end{array}$ & $\begin{array}{l}0.77 \\
0.71 \\
0.63 \\
0.63\end{array}$ \\
\hline
\end{tabular}




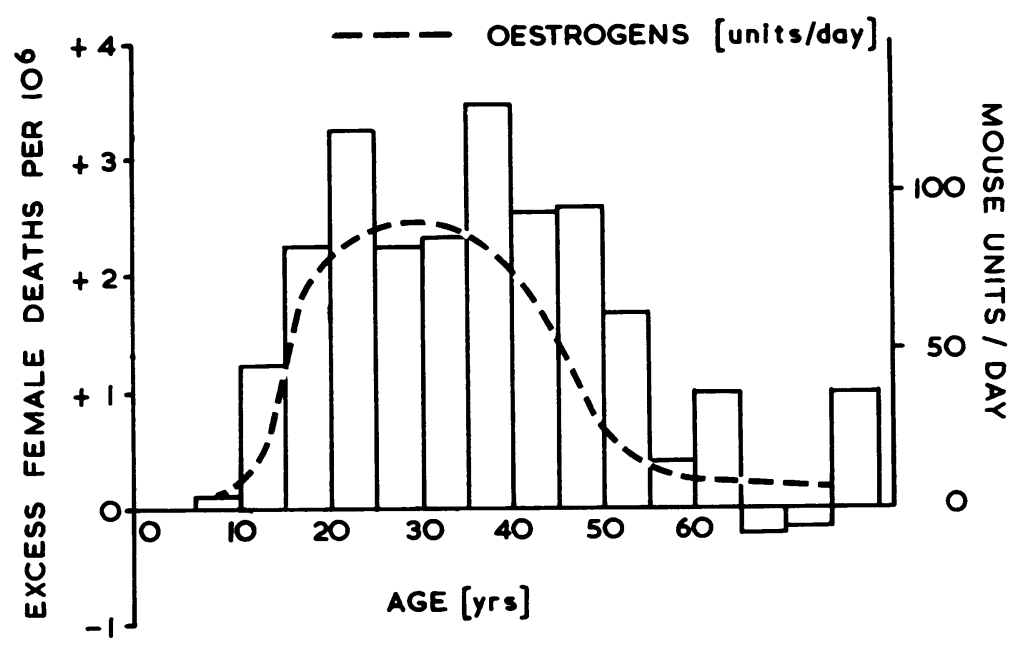

Figure.-(Female-male) death rates from lupus erythematosus, by age, United States, all races, 1956-58 (National Office of Vital Statistics, unpublished data) and mean oestrogen excretion rates, by age, in normal women (Pedersen-Bjergaard and Tønnesen, 1948).

(perhaps more appropriately) öophorectomy in menstruating women with severe S.L.E.-especially perhaps, in cases of lupus nephritis with azotaemia. It also indicates a need for detailed studies in individual patients on the relation between the activity of S.L.E. on the one hand, and pregnancy, menstruation, and hormone levels on the other.

\section{Summary}

(1) A case of systemic lupus erythematosus is reported in which severe nephritis was followed after 3 years of steroid therapy by reversal of azotaemia, hypertension, and proteinuria.

(2) This unusual recovery coincided approximately with the menopause. Statistical evidence related to sex differences in this disease is presented and found to be consistent with the view that the female sex hormones may exert an adverse effect.

I am grateful to Prof. W. S. Peart for permission to publish this case report, and to the Medical Research Council and the United States National Office of Vital Statistics for permission to use their unpublished data.

\section{REFERENCES}

Gold, S. (1960). Brit. J. Derm., 72, 231.

Harvey, A. M., Shulman, L. E., Tumulty, P. A., Conley, C. L., and Schoenrich, E. H. (1954). Medicine (Baltimore), 33, 291.

Merrell, M., and Shulman, L. E. (1955). J. chron. Dis., $1,12$.

Muehrcke, R. C., Kark, R. M., Pirani, C. L., and Pollak, V. E. (1957). Medicine (Baltimore), 36, 1.
Pedersen-Bjergaard, K., and Tønnesen, M. (1948) Acta endocrinol. (Kbh.), 1, 38.

Pollak, V. E. (1961). Personal communication. $\delta \overrightarrow{0}$

Rupe, C. E., and Nickel, S. N. (1959). J. Amer. Ass., 171, 1055.

Soffer, L. J., Ludemann, W. H., and Brill, G. (1950) Ann. N.Y. Acad. Sci., 61, 418.

\section{Cas peu fréquent de rétablissement de lupus érythémateux généralisé}

\section{RÉSUMÉ}

(1) On décrit un cas de lupus érythémateux accom? pagnée d'une néphrite grave qui fut suivie, après trois ans de thérapie stéroïde, par l'inversion de l'azotémie. de l'hypertension et de l'albuminurie.

(2) Ce rétablissement extraordinaire coïncidait à peơ près avec la ménopause. On présente des données statistiques concernant le sexe dans cette maladie et on. les trouve compatibles avec le point de vue que les hormones féminines peuvent y exercer un effet pew favorable.

Un caso poco frecuente de recuperación clínica de lupus eritematoso generalizado

\section{Sumario}

(1) Se describe un caso de lupus eritematoso, co은 nefritis grave, que fué seguida después de 3 años dé terapéutica con esteroides por una reversión de 19 azotemia, hipertensión y proteinuria.

(2) Esta poco usual recuperación coincidió aprox madamente con la menopausia. Se presentan datos estadísticos de esta enfermedad con relación al sexo, que son compatibles con la hipótesis de que las hormonaș sexuales femeninas pueden ejercer un efecto adverso. 